How Should Firms Reconcile Their Open Innovation Capabilities for Incorporating

External Actors in Innovations Aimed at Sustainable Development?

Sarah Behnam (a), Raffaella Cagliano (b), Mercedes Grijalvo (c)

a. Institute of Industrial Technologies and Automation (ITIA) of the National Research

Council of Italy (CNR), sarah.behnam@gmail.com ; sarah.behnam@itia.cnr.it

b. School of Management, Politecnico di Milano, raffaella.cagliano@polimi.it

c. Department of Industrial Management, Business Administration and Statistics, Universidad Politécnica de Madrid (UPM), mercedes.grijalvo@upm.es

Please cite as: Behnam, S., Cagliano, R., \& Grijalvo, M. (2018). How should firms reconcile their open innovation capabilities for incorporating external actors in innovations aimed at sustainable development?. Journal of cleaner production, 170, 950-965.

Doi: https://doi.org/10.1016/j.jclepro.2017.09.168 


\title{
How Should Firms Reconcile Their Open Innovation Capabilities for Incorporating External Actors in Innovations Aimed at Sustainable Development?
}

\begin{abstract}
Subsequent to the decades of research and business advancement in sustainable development, the importance of sustainability is undoubtful; however, existing paths toward it are not yet sufficient. Correspondingly, innovation has recently emerged as a persuasive means to enhance sustainability. As with all conventional innovations, the integration of broad and diverse actors in innovation projects aimed particularly at sustainable development is essential, but it is argued to require reconciliation, owing to the peculiarities of the sustainability context. The innovation literature (particularly the open innovation stream) extensively investigates and is able to provide us with businesses’ capabilities for integrating external actors for conventional innovation projects. Elaborated from the literature, we identify and conceptualize four capabilities as bundles of open conventional innovation capability - namely, networking, competence mapping, relational, and desorptive capabilities. Starting from the conceptual framework of open conventional innovation capabilities, eight innovation projects aimed particularly at sustainability with diverse and broad actors were used as an empirical context for qualitative, multiple-case studies. The results suggest that open sustainability-oriented innovation capabilities conform to the open conventional innovation capability framework; however, the capabilities must be reconciled with the particular sustainability context. In particular, the results suggest that desorptive capability (the ability of aligning/empowering internals for external acquirements) requires particular and strong reconciliation with the sustainability context, whereas the required reconciliation of networking, competence mapping and relational
\end{abstract}


capabilities strongly depends on the outcome characteristics. In this regard, the findings reveal that for innovations to develop a sustainable product-service system that would dramatically change existing systems and consumers’ lifestyles, capability reconciliation is required for all key partners of the project. On the other hand, for innovations to develop a sustainable product or service, established open conventional innovation capabilities can be used.

Keywords: sustainability-oriented innovation, external integration, open innovation, capability development

\section{Abbreviations ${ }^{1}$}

${ }^{1}$ SOI: sustainability-oriented innovation defined as the development of new products, processes, and/or management systems, where environmental, social, and economic goals are their foundations. 


\section{Introduction}

During the last few decades, there has been a surge of interest among scientists, practitioners and even the public toward conserving the environment along with using resources efficiently (ecological concerns), improving the standard of human living (social challenges), and advancing long-term economic competitiveness (economic matters). The concept dealing with these issues is defined as "sustainability", initiated by World Commission on Environment and Development (WECD, 1987), which has been further conceptualized both broadly or narrowly (Brown et al., 1987). In this paper, since we consider a broad concept of sustainability (ecological, socio-economic), we adopt a wide-ranging definition of sustainability, as Elkington (1997) calls for the ‘Triple Bottom Line’ and Rogers et al. (2012) call for 'sustainable development'. These definitions refer to three different main approaches to sustainability:

1. Ecological/environmental: maintaining the robustness and resilience of biological and physical systems;

2. Social/cultural: creating benefits by businesses for society (maintaining the well-fare of civil systems and creating value for stakeholders);

3. Economic: maximizing income while keeping/enhancing the stock of capital (commercially viable).

We treat sustainability as a dynamic and unfolding concept that is achieved over time rather dichotomously (sustainable/not sustainable) (Adams et al., 2016). Thus, practitioners and academicians have been trying to primarily determine whether existing business paths are sustainable, and if not, how firms can incorporate sustainability into their businesses (Nidumolu et al., 2009). Recent progress suggests that innovation is a persuasive means to enhance sustainability in businesses (Dangelico and Pujari, 2010; Hansen et al., 2009; Hart, 1995; Horn 
and Brem, 2013; Seebode et al., 2012) or even a touchstone for all innovations, since both aim at similar goals (bottom-line and top-line returns) (Nidumolu et al., 2009). Schumpeter (1939) defines innovation in the form of new products, processes, methods, markets, and supply sources, on which economy expansion is directly dependent. As Pujari et al. (2003) note, by carrying out a survey analysis of UK firms, a notable “paradigm shift” is present regarding innovations aimed at sustainable development.

As in conventional innovations, in a large number of SOI projects, the incorporation of external actors in (sustainability-oriented) innovations is beneficial in many respects (Sharma and Vredenburg, 1998). However, despite the obvious and many-fold advantages of incorporating external actors for businesses, they face abundant challenges and complexity in doing so (Keskin et al., 2013). Consequently, businesses must develop organizational capabilities to be able to face these challenges (Huizingh, 2011; Sharma and Vredenburg, 1998; van Kleef and Roome, 2007). To provide a theoretical background, a comprehensive review is provided on capabilities for incorporating external actors in both conventional and sustainability-oriented innovations.

Capabilities for incorporating external actors for conventional innovations are comprehensively studied as open innovation capabilities. Open innovation is defined as “a distributed innovation, based on purposively managed knowledge flows across organizational boundaries” (Chesbrough and Bogers, 2014, p. 12). With regard to open innovation capabilities, Lichtenthaler and Lichtenthaler (2009) advance an integrative capability-based framework (including exploration, retention, and exploitation phases of innovation) based on the classic evolutionary variation-selection-retention model (Campbell, 1960). External exploration refers to the acquisition of knowledge from external sources (Lane et al., 2006; Zollo and Winter, 
2002). External exploitation encompasses the replication of new approaches and their application in the business context (Zollo and Winter, 2002). Finally, external retention describes the possibility of incorporating knowledge on interfirm relationships, which represent the external knowledge base.

Since the open innovation capability framework proposed by Lichtenthaler and Lichtenthaler (2009) thoroughly integrates the phases of innovations and elaborates them based on a comprehensive review of literature, we based the theoretical framework of this study on this framework. We further update and advance the framework based on the capability literature from an organizational viewpoint in order to be able to conceptualize the capabilities clearly. To do so, we decompose external exploration into two capability components, namely, networking and competence mapping. Moreover, we conceptualize the external exploitation and retention capabilities from organizational capabilities as relational and desorptive capacities, respectively.

Moreover, the review of the literature on capabilities for incorporating external actors for sustainability-oriented innovations reveals that the sustainability context has peculiarities that require reconciliation for conventional open innovations (Adams et al., 2012; CarrilloHermosilla et al., 2010; van Kleef and Roome, 2007). While this highlights the need for studies on open innovation capabilities for the specific context of sustainability, prior investigations are sparse. Moreover, few studies have focused mainly on relational or desorptive capacities (exploitation or retention); thus, a comprehensive integrated framework of capabilities (networking, competence mapping, relational and desorptive capabilities) is lacking. Furthermore, prior (open) innovation studies clearly show the dependence of capabilities based on innovation type (e.g., Carrillo-Hermosilla et al., 2010), mainly on the combination of product and services (Carrillo-Hermosilla et al., 2010) and the extent of its radicalism (Tukker and 
Butter, 2007). In this regard, the capabilities for incorporating external actors for sustainabilityoriented innovations have not been studied for diverse innovation types (as studies have mainly focused on similar projects).

Accordingly, this study aims at exploring the need to reconcile established open innovation capabilities when particular innovations aimed at sustainability are developed depending on the outcome characteristics. Thus, the study contributes to existing studies not only by shedding light on the lack of comprehensive and empirical analysis on open sustainable innovations but also by investigating the dependence of capabilities according to innovation type.

The paper is structured as follows: First, we provide a theoretical background section (Section 2) with a comprehensive theoretical background on capabilities for incorporating external actors in both conventional (Section 2.1) and sustainability-oriented (Section 2.2) innovations. Consequently, we elaborate the theoretical background to justify the need for exploring the dependence of capability development on innovation type (Section 2.3). Following the theoretical background, the methodology is explained (Section 3), with detailed information on the cases (Section 3.1) and data collection and analysis (Section 3.2). Then, we provide the findings on open sustainability-oriented innovation based on the scrutinized empirics of this study (Section 4.1 to 4.4 - Analysis of each capability), followed by an overall analysis of the findings related to the research question (Section 4.5). Finally, the study presents a discussion of the results (Section 5) and the conclusion.

\section{Theoretical background}


Innovations aimed at sustainable development have been studied through diverse terminologies and research streams, including the following:

-Sustainability-oriented (or related, driven, led) innovation (Hall and Vredenburg, 2003; Seebode et al., 2012; Wagner and Llerena, 2008)

-Sustainable (development) innovation (Bos-Brouwers, 2010; Hall, 2002)

-Eco (or green, environmental) innovation (Fussler and James, 1996)

-Environmental or green (new) product development (Dangelico and Pujari, 2010;

de Medeiros et al., 2014).

Within the related multidisciplinary research streams related to the topic, eco/greeninnovation/product development has been more extensively investigated (Klewitz and Hansen, 2014), which focuses solely on environmental issues mainly regarding new product development (e.g., Hart, 1997; Pujari, 2006). However, product environmental innovations are generally induced by public policy or oriented toward the market (Hall and Vredenburg, 2003); thus, they include fewer disruptive innovations (Pujari, 2006). In this paper, following prior research (e.g., Ketata et al., 2015), a broad definition of sustainability is chosen to include also social issues. Accordingly, the term sustainability-oriented innovation (SOI) is used - defined as the development of new products, processes, and/or management systems, where environmental, social, and economic goals are their foundations (Hansen et al., 2009).

In addition, compared to other terminologies covering social aspects, sustainabilityoriented innovation has been chosen because the focus is on innovations, which are intended to contribute to sustainable development, independent from the actual sustainability performance of a business (as is the case of sustainable/eco/green innovations). Focusing on the intentionality of sustainable development, compared to the actual impact on sustainability performance, has its 
pros and cons. A clear drawback is that a business must decide which innovation projects, in practice, actually enhance the sustainability performance of the entire business (VINNOVA, 2001). On the other hand, our notion of innovations is similar to that in several previous studies (e.g., Kemp and Pearson, 2008), which is related to the novelty to the firm as an institutional context. This is appropriate because innovativeness is highly context dependent (meaning that a novel innovation for a certain group may be completely commonplace for another group) (Morand, 2008).

Innovations targeting sustainable development play a crucial role in enhancing sustainability in businesses (Belz, 2013), and they are even necessary (de Medeiros et al., 2014; Gmelin and Seuring, 2014; Koebel, 1999; Pujari, 2006). To develop successful (sustainabilityoriented) innovations, diverse actors must be incorporated, mainly to provide lacking/new insights (Ayuso et al., 2006; Hansen et al., 2009; Laperche and Picard, 2013), to promote a sustainability mindset in the involved actors (Carter and Rogers, 2008; Jelsma, 2003; Lockton et al., 2008) and to enhance stakeholder satisfaction, trust, and commitment (Grafé-Buckens and Hinton, 1998; Strong et al., 2001). The review of the literature shows that generally and particularly in the sustainability literature the integration of external actors refers to stakeholder integration where a stakeholder is any actor involved in a project, ranging from individuals to groups or whole organizations. Thus, stakeholders can come from both within or outside the organization's boundaries. This definition is close to Freeman and Evan's (1990), Hill and Jones' (1992), and Cornell and Shapiro's (1987) definitions, where stakeholders are contractors or participants in exchange relationships. Considering this definition of stakeholders, in the innovation literature, stakeholder integration for sustainability is in line with organizational constructs related to open innovation (Gould, 2012). 


\subsection{Capabilities to incorporate external actors in conventional and sustainability-oriented}

\section{innovations}

Organizational capabilities have been viewed through different theoretical lenses, such as neoclassical economics (e.g., Amit and Schoemaker, 1993; Peteraf, 1993), evolutionary economics (e.g., Nelson and Winter, 1982) and organizational theory (e.g., Eisenhardt and Martin, 2000). In this study, we look at organizational capabilities from organizational theory, where they are defined as a set of processes enabling firms to achieve a certain outcome (Eisenhardt and Martin, 2000). The capability view has been widely recognized because of its potential to improve the understanding of businesses’ capacity to deploy resources for a defined purpose (Andrews, 1971; Hofer and Schendel, 1978; Prahalad and Hamel, 1990; Ulrich and Lake, 1991).

To provide a comprehensive review of the capability literature on (sustainabilityoriented) innovation projects, a multi-terminology multi-disciplinary approach is applied ${ }^{2}$.

\footnotetext{
2 To identify the relevant papers for the topic in the sustainability literature, we searched sustainability and stakeholder in the abstract of papers in two main databases (Emerald (15 relevant papers were selected initially) and IEEE (50 relevant papers were selected initially). On the other hand, for the innovation literature, because there were numerous papers, two sets of keywords were examined in the papers' titles/abstracts/keywords in the Scopus database (namely, stakeholder integration capability AND innovation (one paper was identified as initially relevant within all matched papers (16)) and stakeholder involvement AND innovation process (six papers were identified as initially relevant within all matched papers (54)). In addition, to review the open innovation literature, as the most extensive literature on the topic, we referred to the most well-known and cited papers in addition to some recent review papers on open innovation (the main ones are Gassmann et al., 2010; Huizingh, 2011; Lichtenthaler, 2011; van de Vrande et al., 2009; West and Bogers, 2014; Ye and Kankanhalli, 2013). These papers helped us through citations -identify the papers relevant to the open innovation capability literature (in addition to the review papers, about 35 papers were finally selected as the most relevant). Finally, regarding stakeholder co-creation, the capability framework for sustainability/stakeholder integration, and external integration for product development, we found another fifteen papers. To review the papers on sustainability-oriented innovation, some sets of keywords were searched in abstracts in Web of Science, Science Direct and Scopus (five relevant papers were finally selected) (the keywords were sustainability/environment/social/green AND innovation/NPD AND stakeholder; sustainability/environment/social/green AND innovation/NPD AND open/external.
} 
2.1.1 Capabilities to incorporate external actors in conventional innovations (typology, definitions, and their conceptualization)

Lichtenthaler and Lichtenthaler (2009) integrate diverse perspectives and propose an integrative open conventional innovation framework, differentiating capabilities, on one hand, based on the exploration/exploitation/retention phases of innovation and, on the other hand, according to the internal and external boundaries of the organization (Lichtenthaler and Lichtenthaler, 2009). Given the purpose of this study, to understand the incorporation of external capabilities, we focus only on the proposed external exploration, exploitation and retention. Of course, the external investigation does not exclude the critical element of devoting investments to align external acquisitions internally - retention (e.g. Cohen and Levinthal, 1990; Nonaka, 1994).

The review of the literature on the proposed capabilities of external exploration shows that firms for external exploration should be able to possess absorptive capacity (from a knowledge management perspective), defined as the ability to transfer knowledge from external actors (Cohen and Levinthal, 1990). From an organizational capability perspective, the external exploration capability refers to the ability to attract external entities (networking capability) and map their competences (competence mapping capability) (Kazadi et al., 2016). Networking capability is defined as a firm's ability to attract external actors to be engaged in an innovation project with the leading firm (Perks and Moxey, 2011). Kazadi et al. (2016) argue that businesses require a more elaborated type of networking capability when integrating a diverse range of actors, especially with non-business actors for non-financial goals. On the other hand, competence mapping capability is defined as "a firm's ability to produce an explicit overview of the different competences present in each of its different stakeholders” (Kazadi et al., 2016, p. 
534). They argue that when an actor is far from the leading firm’s business, identifying the competences of each actor would be much more challenging and complex (Kazadi et al., 2016). Regarding external exploitation, connective capacity is crucial, referring to the relationships of the actors and a firm's ability to retain knowledge in interfirm relationships (Lichtenthaler and Lichtenthaler, 2009). Thus, it encompasses elements of relational capability, mainly aligned with our definition of actors' involvement in a project (Lorenzoni and Lipparini, 1999), and alliance capability, refers mainly with reference to long-term interfirm relationships (Kale and Singh, 2007). Relational capability is defined as an organization's ability to manage relationships with actors involved in projects by building an innovation network (Capaldo, 2007). Mitrega et al. (2012) suggest a combination of relationship initiation, relationship development and relationship termination. The common theme in the defi-nitions is relational capability (Capaldo, 2007; Lorenzoni and Lipparini, 1999). However, it is argued that if the involved actors are required to have an active and positive relationship with each other (not limited to dyadic relationships), additional relational capabilities are required. Some studies recognize relational capability as the key element of stakeholder integration (e.g., van Lancker et al., 2016).

Finally, a firm’s ability regarding external knowledge retention, called as desorptive capacity, relates to the execution of external acquirements internally and within the boundaries of the organization (Lichtenthaler, 2007). The rational lies in the fact that after identifying external knowledge exploitation opportunities, a firm has to accommodate the knowledge internally (Rivette and Kline, 2000). This capability refers to the firm’s ability to select, engage, empower, and align relevant internal actors with external acquisitions in a project (e.g., Hillebrand and Biemans, 2003, 2004). The majority of innovation studies on internal cooperation have focused 
on the cooperation between functions (e.g., Griffin and Hauser, 1996), especially in new product development (Hillebrand and Biemans, 2004). However, desorptive capacity is very difficult to acquire in a business and is shown not to be a single best solution, while "a contingency approach appears to offer the best chance of success” (Hillebrand and Biemans, 2004, p. 736). To conclude, through the elaboration of prior open innovation research, four capabilities can be identified as the fundamental components of incorporating external actors into open innovation projects: namely, networking, competence mapping, relational and desorptive capabilities/capacities. To give a detailed conceptualization of the identified capabilities - and thus build a robust research protocol for the empirical setting - a comprehensive literature review of the conceptualization of the four capabilities is carried out (Table 1). 
Table 1. Conceptualization of the identified four capabilities (networking, competence mapping, relational and desorptive capabilities) - elaborated based on a comprehensive literature review

\begin{tabular}{|c|c|c|c|}
\hline \multicolumn{2}{|c|}{ Capability and Definition } & Conceptualization & Key References \\
\hline 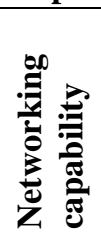 & $\begin{array}{l}\text { A firm's ability to attract external } \\
\text { actors to be engaged in a project } \\
\text { (build [recruit potential partners] } \\
\text { and grow an innovation network). }\end{array}$ & $\begin{array}{l}\text { Communicating consistently about innovation partner selection } \\
\text { criteria and about the types of collaboration partners needed; } \\
\text { engaging in networking opportunities within a diverse range of } \\
\text { external actors. }\end{array}$ & $\begin{array}{l}\text { Dangelico et al. (2013), Kazadi et } \\
\text { al. (2016), Perks and Moxey (2011), } \\
\text { Perry (2015), Sharma and } \\
\text { Vredenburg (1998), Steiner (2008), } \\
\text { van Kleef and Roome (2007), } \\
\text { Verhoeven and Maritz (2012) }\end{array}$ \\
\hline 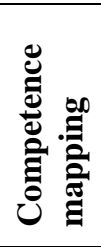 & $\begin{array}{l}\text { A firm's ability to produce an } \\
\text { explicit overview of the } \\
\text { competencies of external entities. }\end{array}$ & $\begin{array}{l}\text { Regularly conducting explorative meetings with partners; } \\
\text { documenting stakeholder competency assessments explicitly; } \\
\text { disseminating stakeholder competency assessments internally; } \\
\text { being able to evaluate types of stakeholders systematically and to } \\
\text { select then appropriately when complementary resources are } \\
\text { integrated. }\end{array}$ & $\begin{array}{l}\text { Kazadi et al. (2016) Sharma and } \\
\text { Vredenburg (1998) }\end{array}$ \\
\hline 预 & $\begin{array}{l}\text { A firm's ability to manage its } \\
\text { network by managing the different } \\
\text { relationships (with a } \\
\text { comprehensive set of } \\
\text { entities/individuals). }\end{array}$ & $\begin{array}{l}\text { Investing in the build-up of stakeholder relationships; engaging in } \\
\text { trust-building activities; engaging in goal identification exercises; } \\
\text { having dedicated team members for relationship management } \\
\text { issues (i.e., understanding the nature of collaboration and } \\
\text { compatibility of partners, establishing shared visions/goals, and } \\
\text { effectively distributing information and new } \\
\text { insights/perspectives); having shared experiences and a history of } \\
\text { collaboration; facilitating smooth, continuous communication. }\end{array}$ & $\begin{array}{l}\text { Ayuso et al. (2006), Capaldo } \\
\text { (2007), Dangelico et al. (2013), van } \\
\text { Kleef and Roome (2007), } \\
\text { Veldhuizen et al. (2012) }\end{array}$ \\
\hline : & $\begin{array}{l}\text { The ability to select, engage, } \\
\text { empower, and align relevant } \\
\text { internal actors to external actors in } \\
\text { a project. }\end{array}$ & $\begin{array}{l}\text { Systematically and effectively selecting the relevant/competent } \\
\text { and internal departments/teams for a project with external actors; } \\
\text { systematically empowering employees for enhanced commitment } \\
\text { to collaborate with external actors (e.g., through systematically } \\
\text { internally sharing information gained from external actors, hiring } \\
\text { expert employees for aligning human resources and projects with } \\
\text { external actors, assigning boundary people who transfer } \\
\text { information between organizational groups to align groups in } \\
\text { terms of their objectives, languages, time frames, and norms in } \\
\text { cross-functional teams). }\end{array}$ & $\begin{array}{l}\text { Ayuso et al. (2006), Ayuso et al. } \\
\text { (2011), Hillebrand and Biemans } \\
\text { (2004), Maltz and Kohli (2000), } \\
\text { Sharma and Vredenburg (1998), } \\
\text { Tushman (1977), Verona (1999) }\end{array}$ \\
\hline
\end{tabular}


2.1.2 Capabilities to incorporate external actors in sustainability-oriented innovations (the need for exploring open innovation capabilities in this particular context)

It is argued that SOI engenders peculiarities compared to conventional forms of innovation from various perspectives, e.g., capability development (e.g., Van Kleef and Room, 2007) and external/internal cooperation/coordination (e.g., Pujari, 2006; van Kleef and Roome, 2007). These peculiarities are argued to be due to the multidimensional objective of SOI (de Marchi, 2012; Foxon and Andersen, 2009), its expected higher level of outcome uncertainty (Sarkis et al., 2010) and its higher number of sustainability-specific stakeholders (van Kleef and Roome, 2007). Regarding the last factor, it is argued that the sustainability context requires more diverse and particular sustainable partners - e.g., NGOs, customers and locally involved people (de Marchi, 2012; Foster and Green, 2000; Laperche and Picard, 2013; Perl-Vorbach et al., 2014; van Kleef and Roome, 2007). The peculiarities of the sustainable context are also confirmed by the innovation literature, which states that the effectiveness of collaboration for innovation depends on the context (Huizingh, 2011). However, as Pujari et al. (2003) claim, there may be more synergies than conflicts; thus, innovation theories and frameworks may support the investigation of SOI projects. Thus, the effective integration of these paradigms could be one of the key challenging benefits for both academics and practitioners in both fields (Pujari, 2006). A comprehensive investigation of capabilities to incorporate external actors in the SOI context, from open innovation theories, is necessary because it can highlight the peculiarities of this context (Adams et al., 2012; Carrillo-Hermosilla et al., 2010; van Kleef and Roome, 2007), allowing firms to be able to reconcile open innovation capabilities with the specific context of sustainable development. 
Accordingly, in the following, we review the literature on open innovation capabilities in the specific sustainability context. The review of the literature on sustainability-oriented innovation shows that there is limited documented evidence on the incorporation of external actors. Within this literature, Ayuso et al. (2006) qualitatively conceptualize external integration capability for SOIs by using two constructs: dialogue and knowledge integration, which refers to the relational capability of open conventional innovations. In addition, in the sustainability context, scholars relate the relational capability to desorptive capacity by quantitatively showing that actors' knowledge must be internally managed by the business to be converted into new ideas (Ayuso et al., 2011). Building on this conceptualization, Veldhuizen et al. (2012) show how desorptive capacity can act as a driver of relational capability.

Further, some scholars investigate relational capability in green/sustainable new product development. In this regard, Dangelico et al. (2013) suggest that relational capability for green new product development should encompass the creation of collaborative networks with actors along and beyond the supply chain and should include the acquisition of technical sustainabilityspecific knowledge. In a similar vein to relational capability for SOI development, Driessen and Hillebrand (2013) identify coordination and prioritization mechanisms as critical elements, which relate to the relationship management and competence mapping capabilities of open conventional capabilities. They suggest that integrating disparate types of actors (market and non-market) requires organizations to build more elaborated capabilities in order to overcome the possible complexity.

To conclude, investigations on open innovation capabilities in the specific sustainability context are sparse, and the few existing studies have mainly focused on relational capability - its relation to desorptive capability; thus, they have not fully covered the capabilities suggested by 
open conventional innovation literature (networking, competence mapping, relational and desorptive capabilities). Thus, an empirical analysis based on the open conventional innovation framework that comprehends all the proposed capabilities to clarify the peculiarities of open sustainable innovation capabilities is lacking.

\subsection{Dependence of capability development on innovation type}

According to prior (open) innovation studies, required capabilities can be dependent on the output - innovation - type (e.g., Carrillo-Hermosilla et al., 2010). In particular, two main aspects have been reported to be relevant: first, the combination of product and services (CarrilloHermosilla et al., 2010); second, the extent of the innovation radicalism (Tukker and Butter, 2007).

Concerning the former (combination of product and service), the literature mainly differentiates between developing solely a product or service, in contrast to product-service systems (PSS) (van Halen et al., 2005), which is simply where a firm offers a set of products and services to fulfil customer needs (also referred to as servitization (Vandermerwe and Rada, 1988)). It has been argued that the development of an innovative product-service system affects the value network to a greater extent than development of a particular product or service (Könnölä and Unruh, 2007). The PSS by nature involves innovations related to the businesses model/value proposition of firms. On the other hand, in line with this study, a service-led competitive strategy is strongly linked to sustainable development (Baines et al., 2007; Mont, 2002). It is also argued that product-service system (PSS) innovation is a promising approach to address sustainability challenges (Manzini and Vezzoli, 2003; Tukker and Tischner, 2006). 
It is strongly argued that the product-service combination of innovation output influences the required capabilities. The relevance of product-service combination for capability investigations is so critical that studies even define PSS/servitization to involve changes to an organization's capabilities and processes to conceive mutual value through a shift from products to a PSS (Neely, 2008). In this regard, it has been argued that the way in which the combination of products and services creates value is related to the entire supply chain perspective (Linton et al., 2007), which affects the level and/or nature of partnerships. This is specifically seen in the literature, where product development studies place more emphasis on networking capability than the other suggested capabilities (Dangelico et al., 2013; Driessen and Hillebrand, 2013). Additionally, different actors - composing “a value network" - are needed to create benefits in developing the product-service system rather than being limited only to the value chain (Könnölä and Unruh, 2007).

Concerning the latter (level of radicalism), for the purpose of this paper, we distinguish between radical and incremental changes (Freeman and Perez, 1988) that are brought about by the SOI project (Carrillo-Hermosilla et al., 2010):

-Incremental changes refer to gradual modifications that preserve existing production systems that create benefits in the existing system.

-Radical changes, in contrast, are discontinuous changes that seek the replacement of existing components or entire systems.

We adopt a firm's perspective to examine the degree of novelty of innovations that have been developed in projects. It is argued that incremental modifications are developed mainly in existing networks, while radical changes seek the creation of new networks to create added value (Carrillo-Hermosilla et al., 2010). However, various terminologies have been proposed to discern 
the level of "radicalism" of innovations (e.g., Christensen, 1997) distinguishes between sustaining innovations and disrupting innovations). Disruptive sustainable manufacturing initiatives, such as closed-loop production, arise through dynamic interaction with diverse actors, which affects the innovation process (Carrillo-Hermosilla et al., 2010). It is also important to note that the two dimensions that characterize innovation types are argued to be interconnected in a way that systemic changes generally embody a higher level of radicalism (OECD, 2009).

To conclude, we define innovations aimed at the development of an innovative sustainable product or service that includes an incremental modification to the existing system of businesses and customers' sustainable lifestyles as unidimensional innovations. On the other hand, innovations aimed at the development of a mix of products and services, with architectures that are expected to dramatically change the existing systems and the lifestyles of customers, are defined as systemic innovations.

Within systemic SOIs, the key actors collaborate — which is close to the definition of codevelopment -from the beginning phases of the project to the end (Perl-Vorbach et al., 2014) in order to develop a mixed product-service system that disrupts the existing system (Markides, 2006). Mont (2002) and Williams (2007) advocate for the application of systemic innovations to develop sustainable business models, which refer to a system of products, services, supporting networks and infrastructure that is designed to be more sustainable.

For example, we can refer to some examples to clarify the differentiation between unidimensional and systemic innovation for sustainability, e.g., mobility sharing rather than environmental friendly vehicle ownership or smart grid systems rather than energy efficient smart home appliances. 
To conclude, by answering to the research question below, this study attempts to reflect on two major gaps in the literature: on the one hand, the lack of comprehensive and empirical analysis on open sustainable innovations; and on the other hand, the lack of investigations of the dependence of open innovation capabilities in the sustainability context on innovation type.

RQ. Which open innovation capabilities should be reconciled by firms for particular innovations aimed at sustainability depending on the radicalism and the product/service combination of the output? ${ }^{3}$

To answer the research question, an exploratory approach was applied, using the proposed open innovation capability-based framework as a guide to gather and analyze the empirical data. Based on the literature review, we anticipate that the open innovation capabilitybased framework is an appropriate lens for an investigation of SOI; however, the SOI context may engender a different emphasis on certain types of capabilities, depending on the radicalism and product/service combination of the outcome.

\section{Methodology}

A qualitative, multiple-case study methodology was chosen to answer the research question of this study. First, research on the sustainability aspects of innovations is at an early stage, and there is a lack of empirical research on the topic (Yin, 2013). Second, qualitative data gathering is especially applicable when a study's constructs are associated with various terminologies and conceptions by academicians and practitioners, requiring deep insights and conversations

\footnotetext{
${ }^{3}$ In particular, by this, we mean whether the already possessed open innovation capability of the actor(s) was enough or required reconciliation during the SOI project. Accordingly, if it requires reconciliation owing to the particular sustainability context, it may require an alternative capability or simply an enhancement of the capability related to the particular context of sustainability.
} 
(Alvesson and Sköldberg, 2009). Innovation, sustainability and external integration are typical concepts that can be interpreted in various ways and from various perspectives. Thus, long conversations are required to develop definitions of the constructs. Finally, the variety of SOI projects suggests that the relationships between outcome characteristics and capabilities are path dependent (Bos-Brouwers, 2010; Mahoney, 2000), so a detailed case study was chosen since it is recommended for evaluating path-dependent processes (Mahoney, 2000).

\subsection{Cases}

Eight SOI projects at firms in Italy and Spain were selected as the case studies, with the project as the unit of analysis. The firms were selected based on their highly proactive approach toward open sustainable innovation, while SOI projects in each firm were selected based on several criteria:

1) The project should have aimed at developing an innovative output for sustainability, with the involvement of at least two external stakeholders. Actors can range from organizations to teams and/or individuals.

2) The project should have achieved a prototype or tangible outcome, and actors should have been able to finish a pre-defined milestone together. The reason behind this choice was aligned with the purpose of our study, as we examine the successful integration of actors in a project (processes involved) by applying an open innovation paradigm and do not directly analyze products. Accordingly, the outcome of a project (product/service) should be economically viable but not necessarily commercialized. Therefore, the success criteria of the selected projects are related to 
whether the actors reached the goal (e.g., during some projects, milestones are limited to exploration/testing and thus do not necessarily constitute the commercialization of the project's output to the final market).

3) Projects should have been initiated fewer than 5 years before the start of the study, especially to facilitate the accessibility of a project's information.

4) Preference was given to projects during which users were also involved during development to be able to cover possible complexities caused by the integration of non-organizational (individual) types of actors.

5) Preference was given to more radical and information-rich projects (Patton, 1990, p. 169), particularly those possessing rich, available, secondary data.

Based on these criteria and convenience sampling, eight cases were chosen. From these eight cases, we attempted to cover diverse types of projects in terms of sustainability dimensions. In particular, two projects are mainly focused on social goals, one is focused on environmental goals, and the rest (five cases) have both key environmental and social goals. In addition, we tried to cover all different combinations of product/service in the projects. In particular, three projects were aimed at developing a product, one at a service and four at a product-service system. Finally, the cases are diverse in terms of whether they were already commercialized (five non-commercialized - i.e., in pilot development - and three commercialized). Each case’s project is explained in terms of the aim, sustainability aspect, involved partners, defined output (in terms of product, service or product/service system), and commercialization (Table 2). 
Table 2. Case descriptions

\title{
CASE
}

SUSTAINABILITY ASPECT

INVOLVED ACTORS

OUT COMM

PUT $^{4}$ ERCIA

A $\quad$ Development of an innovative technology to

Environmental: recyclability of

-Multinational beer producer (40,435 employees

LIZED

improve draft beer

quality and reduce its

environmental impact

B

containers; decreased $\mathrm{CO}_{2}$ worldwide);

consumption; replaced external air -Users (for testing)

pressure instead of

$\mathrm{CO}_{2}$ Cylinders

generation packaging

material for food

Environmental: near-zero plastic

formula, leading to material

homogeneity for the disposal of

products, with enhanced

recyclability

C Introduction of a smart

ood product packaging

Social: promotion of end user

sustainable behavior in disposal

separation

grid system aimed at

Environmental: enhanced energy

efficiency

integrating new-

Social: reduced energy

generation home

consumption behavior and cost

appliances, energy

provider and energy

system $^{5}$

D Development of a

smart/ICT-based home

interface to improve the

life quality of

disabled/elderly people

E New car sharing

initiative founded in

2010 in a city with very

little experience with

car-sharing

\author{
Social: promotion of independent \\ and autonomous lifestyles for \\ elderly and disabled people with \\ sensorial, cognitive, or mobility \\ problems \\ Environmental: environmentally \\ friendly urban mobility; reduced \\ use of private mobility \\ Social: promotion of non- \\ ownership mobility system
}

-Research institution

-Supplier network (for technology)

-Multinational food manufacturer $(14,000$

employees worldwide)

-User proposing the idea (Market-Push project)

- Professional testers

- Research institution

-Suppliers network (for technology)

-Multinational manufacturer of smart home appliances (10,500 employees worldwide)

-Biggest local utility provider (around 2500 employees)

-Research institution (during the entire project)

-Users and municipality (for testing)

-International, non-profit research center

PSS No

-Home furniture producer

-Users and municipality (for testing)

-External exerts (for technology)

-Industrial network (for technology)

-Manufacturer of electric cars

-Users and municipality (for testing the cars and

the urban infrastructure)

${ }^{4}$ Product: P; Service: S; Product Service System: PSS

${ }^{5}$ Electric grids, electronic meters, renewable energy in-house production system 
F Introduction and application of an ecosystem for electric cars in a city with little experience with ECs

G Introduction of photocatalytic materials for asphalt, pavement, and building surfaces for better air quality in urban areas

H Introduction of annual empowerment initiatives for underprivileged people, according to needs, by businesses.
Social: Change in user behavior toward electric cars

Environmental: enhanced use of environmentally friendly mobility system (e-vehicles)

Environmental: development of materials and measurement methods to prevent pollution Social: development of technologies for application in urban areas to prevent air pollution

Social: employees train

underprivileged people according

to their needs and available

expertise (e.g., how to save money and face economic challenges)
-Multinational mobility utility company

PSS Yes

-Agency of "new uses of energy"

-Users and municipality (for architecture of

infrastructure)

-Research organization linked with an

P No

engineering consultancy, a lead company in

transport engineering (approximately 2,500

employees)

-Suppliers and another research institution for testing and measuring the influence

-Users and municipality for testing

-Multinational manufacturer (121,000 employees

worldwide) of consumer goods linked with an

NGO

-Users (i.e., underprivileged people) for

understanding their needs 


\subsection{Data collection and analysis}

Since in-depth qualitative studies on external integrations rest on documents and interviews with the most key process participants/stakeholders, we attempted to interview at least one person among the involved actors in each project. In three cases (C, E \& G), all involved stakeholders were interviewed. In two cases (D \& H), the only stakeholder who was involved but not interviewed is the user, owing to the confidentiality policy. In case B, the involved actors were the user and technological partner (supporting only the formula development). Regarding the users, who were integrated through an online platform on the firm's website, we performed a content analysis of the communications on the online platform. Therefore, in six cases, we were able to interview all or key stakeholders. Regarding the other two cases (A \& F), owing to confidentiality limitations of the involved stakeholders, we interviewed only the lead company. However, to compensate for the lacking interviews, rich secondary data on the involved actors were gathered.

To select interviewees from each organization, the following criteria were used. They had to take part in the project and still be working for the same company. However, users, as individuals, were interviewed based on convenience selection. Depending on the interviewee and his/her information, to collect answers to all questions, other interviewees were chosen or recommended (by the first interviewee) in some cases for further data collection. Interviews were conducted until all required information was fulfilled. Table 3 contains a list of interviewees (with interview durations) and sources of secondary data for each case. 
Table 3. List of interviews and sources of used secondary data

\begin{tabular}{|c|c|c|c|}
\hline & Stakeholder & Min & Source of secondary data/Interviewee position \\
\hline \multirow{3}{*}{ A } & Project's secondary data & & Press company archive, 2012; Project report and online sources \\
\hline & \multirow[t]{2}{*}{ Manufacturer } & 45 & Corporate affairs manager \\
\hline & & & Secondary data (Online innovation reports of the branch; sustainability reports 2011 to 2014) \\
\hline \multirow{5}{*}{ B } & \multirow[t]{4}{*}{ Manufacturer } & 20 & Local marketing director \\
\hline & & 45 & Local marketing director \\
\hline & & 50 & Technical development director, packaging design, and standards director \\
\hline & & & Secondary data (branch website; branch’s report on recyclability and recycling of packaging) \\
\hline & User & & Secondary data (content analysis of firm-user online platform) \\
\hline \multirow{10}{*}{$\mathbf{C}$} & Project’s secondary data & & Project's website and online sources \\
\hline & \multirow[t]{2}{*}{ Involved research institution } & 85 & Associate professor, energy department \\
\hline & & 40 & \\
\hline & \multirow[t]{2}{*}{ Energy provider } & 120 & Energy-provider consultant \\
\hline & & & $\begin{array}{l}\text { Secondary data (full report and presentation of the former smart grid project; project presentation; } \\
\text { academic publications from the project) }\end{array}$ \\
\hline & \multirow{2}{*}{$\begin{array}{l}\text { Manufacturer of home } \\
\text { appliances }\end{array}$} & 60 & Energy and sustainability manager \\
\hline & & & Secondary data (sustainability reports) \\
\hline & \multirow[t]{3}{*}{ End user } & 40 & User \\
\hline & & 30 & \\
\hline & & & $\begin{array}{l}\text { Secondary data (users' contracts; classifications; questionnaire used for feedback; presentation of } \\
\text { users' feedbacks) }\end{array}$ \\
\hline \multirow{4}{*}{$\mathbf{D}$} & Project's secondary data & & Project's website and online sources \\
\hline & \multirow{3}{*}{$\begin{array}{l}\text { Research institute } \\
\text { (Project leader) }\end{array}$} & 105 & Director \\
\hline & & 45 & \\
\hline & & & Secondary data (company’s website) \\
\hline \multirow{5}{*}{$\mathbf{E}$} & \multirow[t]{2}{*}{ Mobility sharing business } & 75 & Communication director \\
\hline & & & Secondary data (company’s website) \\
\hline & \multirow[t]{2}{*}{ End user } & 30 & Two customers \\
\hline & & 30 & \\
\hline & International consulting firm & & Secondary data (full report of 2015 customer value leadership award; company’s website) \\
\hline \multirow{3}{*}{$\mathbf{F}$} & \multirow[t]{3}{*}{ Electric car manufacturer } & \multirow[t]{3}{*}{50} & Project manager \\
\hline & & & Assistant manager of electric vehicles in the innovation department \\
\hline & & & Secondary data (corporate governance, 2014; legal documentation 2014; activity report, 2014; \\
\hline
\end{tabular}




\begin{tabular}{|c|c|c|c|}
\hline & & & sustainability report, 2014; publication of the project; project's catalogs) \\
\hline & Industry partner & & Secondary data (agreement; sustainable mobility report; seven latest reports on products) \\
\hline & Industry network & & Secondary data (industry network’s report on electrical vehicles). \\
\hline \multirow{3}{*}{ G } & City hall & 30 & General director of city maintenance, utilities and transport \\
\hline & $\begin{array}{l}\text { The engineering-consultancy } \\
\text { organization }\end{array}$ & 55 & $\begin{array}{l}\text { General director of waste, water and environment branch of the department of engineering and } \\
\text { services }\end{array}$ \\
\hline & Research organization & 70 & Technical coordinator of scientific technical development \\
\hline \multirow{5}{*}{$\mathbf{H}$} & Project's secondary data & & $\begin{array}{l}\text { Project report and catalogues; joint written answers to delivered general questions to be asked } \\
\text { during the interview }\end{array}$ \\
\hline & \multirow[t]{2}{*}{ Manufacturer } & \multirow[t]{2}{*}{55} & Group manager of external relations \\
\hline & & & Secondary data (company website; sustainability report) \\
\hline & \multirow[t]{2}{*}{ International NGO } & \multirow[t]{2}{*}{55} & Businesses' loyalty responsible \\
\hline & & & Brand and fundraising director \\
\hline
\end{tabular}


A set of questions was developed to gather data from organizations or individuals. Accordingly, two questionnaires were designed, one for organizations/groups (either lead organizations or their partners) and one for individuals. Because of the large number of questions, they were grouped and were delivered to the interviewees as discussion topics prior to the interviews. The main topics covered in the interviews were as follows: general explanation of the SOI project, detailed explanation of each phase of the project; stakeholder integration process at each phase of the project; information-sharing process among various stakeholders; stakeholder identification and selection process; key inputs from each stakeholder in the whole innovation process; evaluation of engagement and dialogue in the collaborations; microfoundations for communication and relationship management; departments/centers/teams/focal actors involved in the project and their duties/roles; internal involvement and empowerment process during external stakeholder integration; complexities and non-efficient causes; technological knowledge processing; importance of each capability; and ways of reconciling the capabilities if needed (for more details on the discussed topics, please refer to Table 4).

The interviews were recorded and transcribed for data analysis and analyzed through coding (Charmez, 1983). Detailed analysis of the cases was used to assess project members' perceptions regarding the importance of identified capabilities (networking, competence mapping, relational and desorptive capabilities). Single case analysis was used to examine the capabilities by deploying theories-in-use (Argyris and Schön, 1997), based on the literature conceptualizing the capabilities (please refer to Table 1). Cross-case analysis was performed by searching for similar/disparate patterns through data comparisons across all cases. Finally, corroboration of one data type through evidence from another was performed based on single and cross-case analyses. All data analysis steps were discussed continuously among the authors 
and, when possible, with other scholars, ensuring the reliability of data analysis. The topics

discussed in the interviews, in addition to their interlinkedness with the coding scheme, are

provided in Table 4.

Table 4. Topics during interviews, linked with data analysis and theoretical background

\begin{tabular}{|c|c|}
\hline Topics & $\begin{array}{l}\text { Links to data analysis and } \\
\text { theoretical background }\end{array}$ \\
\hline \multicolumn{2}{|l|}{ Involved organization } \\
\hline $\begin{array}{l}\text { Explanation of the project, including drivers and primary goals, expected outcome, } \\
\text { and outcome's target market for success/failure factors of the project's outcome }\end{array}$ & $\begin{array}{l}\text { Ensuring the suitability of the case for the } \\
\text { study and progress of the project. }\end{array}$ \\
\hline $\begin{array}{l}\text { Detailed explanation of each phase of the project (i.e., idea generation, } \\
\text { development, testing/validation, and commercialization) }\end{array}$ & $\begin{array}{l}\text { Introduction to each phase of the project } \\
\text { (next Q) }\end{array}$ \\
\hline $\begin{array}{l}\text { Stakeholder integration at each phase of the project, including } \\
\text { who/how/when/roles/outcomes/(dis)advantages }\end{array}$ & $\begin{array}{l}\text { Importance of networking capability and } \\
\text { stakeholder's peculiarity }\end{array}$ \\
\hline $\begin{array}{l}\text { Information-sharing among various stakeholders; decision making throughout the } \\
\text { project with all stakeholders }\end{array}$ & $\begin{array}{l}\text { Networking capability micro-foundations } \\
\text { to understand the possession of the } \\
\text { capability }\end{array}$ \\
\hline Stakeholder identification and importance and challenges of selection capability & $\begin{array}{l}\text { Importance of competence mapping } \\
\text { capability’s }\end{array}$ \\
\hline $\begin{array}{l}\text { Inputs from each stakeholder during the project, including through which } \\
\text { mechanism/with what aim }\end{array}$ & $\begin{array}{l}\text { Possession of competence mapping } \\
\text { capability and stakeholders' peculiarities }\end{array}$ \\
\hline $\begin{array}{l}\text { Evaluation of engagement/dialogue ability through collaboration with various } \\
\text { stakeholders in terms of importance and challenges }\end{array}$ & $\begin{array}{l}\text { Importance of relational capability and } \\
\text { stakeholder's peculiarity }\end{array}$ \\
\hline Micro-foundations for communication and relationship management & Possession of relational capability \\
\hline $\begin{array}{l}\text { Departments/centers/teams/focal actors of the company involved in the project and } \\
\text { their roles. Co-existence of internal integration with external integration, as well as } \\
\text { the reasons and mechanisms }\end{array}$ & Possession of desorptive Capacity \\
\hline $\begin{array}{l}\text { Necessity of involvement and empowerment during stakeholder integration and the } \\
\text { mechanisms }\end{array}$ & $\begin{array}{l}\text { Importance and possession of desorptive } \\
\text { capacity }\end{array}$ \\
\hline $\begin{array}{l}\text { Complexity and importance of external information for value capturing; managing } \\
\text { efficiency increases during information exchanges and the mechanisms }\end{array}$ & \multirow{3}{*}{$\begin{array}{l}\text { Open questions to enhance the richness of } \\
\text { data/collect any missing data and validate } \\
\text { their prior responses }\end{array}$} \\
\hline Handling technological knowledge gaps between stakeholders & \\
\hline $\begin{array}{l}\text { The importance of each ability during each phase and ways of enhancing them if } \\
\text { needed; learned lessons; difficulties during projects and ways to deal with conflicts } \\
\text { of interest among stakeholders; perceived need to develop new abilities during a } \\
\text { project/any developed or improved ability-facilitating factors for stakeholder } \\
\text { integration; influencing factors regarding how to engage actors in a project; } \\
\text { company's orientation toward stakeholder integration; sustainability brought to a } \\
\text { typical open innovation project }\end{array}$ & \\
\hline \multicolumn{2}{|l|}{ User } \\
\hline \multicolumn{2}{|c|}{$\begin{array}{l}\text { Gains and motivations from participation; method of involvement; stage of involvement; disparate expectations with reality; } \\
\text { communication and its role; the role of other stakeholders; existence of tensions in relationships; degree of integration; } \\
\text { description of the experience; difficulties; proposed product and differences from traditional ones; sustainability aspects and } \\
\text { users' perceptions; change led by involvement with users' lifestyles or perceptions of organizations or sustainable development; } \\
\text { potential improvement points }\end{array}$} \\
\hline
\end{tabular}


Regarding the qualitative analysis of the answers, based on a coding scheme, we assigned the perceived importance of each capability based on our synthesis of the qualitative data. To do so and to ensure the reliability of the answers, we synthesized the responses to two sets of questions (indirect and direct questions):

1. The synthesis of the interviewees' responses to indirect questions:

For the synthesis of the relative importance of indirect questions, we analyzed the responses to the questions regarding the success factors and major challenges of integrating external actors in the SOI project. Moreover, to indirectly synthesize whether the responder possessed/developed the capability during the SOI project and the required reconciliation degree of capabilities, we analyzed the responses to questions regarding the actors' roles, duties and activities as well as the mechanisms needed to give the responder networking, competence mapping, relational and desorptive capabilities (based on the theoretical background - Table 1). In other words, we asked the interviewees if/how reconciliation was required and how it was carried out in the mechanisms underlying the conceptualization of each capability, without directly announcing the capabilities' labels. Finally, to ensure the reliability of answers to whether/how the already open innovation capability was enough or required reconciliation for the particular sustainability context, we merged the responses regarding the possession/reconciliation of capabilities with the faced challenges and complexities. Finally, the way actor(s) coped with the upcoming challenge, if any, due to the particular sustainability context, supports the validity of our synthesis.

2. At the end of the interviews, direct questions were also asked regarding the relative importance/criticalities of the hypothesized capabilities for the specific sustainability 
context of the projects. To do so, we gave the definition of the capabilities in the theoretical background (Table 1) to the interviewees and asked them to rank the capabilities based on their criticality/importance/required reconciliation for the sustainability context. The interviewees had to rank the capabilities from the most to the least critical capability. The importance of capabilities was assessed to make sure that the pre-conception of the appropriateness of innovation frameworks/theories for SOI investigation was valid for our empirical setting. Building upon the direct questions - and considering the alignment with the results of the indirect analysis -we assigned a scaling of the perceived importance of each capability, from 1 to 5, where 1 represents capabilities that were the least important, 2 to 4 represent capabilities that were relatively important but not considered success factors/major challenges in the external integration, and 5 represents capabilities that were quite important and considered success factors.

\section{Findings}

To be able to provide concrete findings from the case study, we conducted a cross-case analysis on the each of the capabilities defined in the theoretical background - networking, competence mapping, relational and desorptive capabilities.

\subsection{Networking capability}

The results suggest two different patterns in the perceived organizations' ability to attract external actors to be engaged in the SOI project. On the one hand, in cases C, D, E, F, and H, project members saw this ability as very important and as a success factor. Since key actors were collaborating throughout the whole project, all of them - not only the lead organization - 
contributed in identifying other actors to be engaged. In these cases, all key involved actors faced extensive challenges in attracting other potential actors according to the particular sustainability context. Accordingly, they were pushed to reconcile their ability collaboratively, mainly by continuously and extensively communicating about potential partner types and the selection criteria to be used, according to the particular context of sustainability. In these cases, the project members enhanced their capability mainly through engaging in various networking opportunities (Kazadi et al., 2016; van Kleef and Roome, 2007). The interesting results show that in these cases, not only the lead organization but all key actors attempted to enhance networking capability collaboratively based on their complementary competences. As a professor of an involved university in case C stated:

The manufacturer and the energy provider established discussion groups in the foundation with all key actors for facing challenges (of attracting other potential actors). Thus, collaboratively, we found a valid and successful solution on how to initiate relationships with users (to be involved intensively in the particular context of sustainability).

On the other hand, in cases A, B, and G, the involved actors - apart from the lead organization - were integrated at various stages, but the lead organization was the primary actor during all stages. Accordingly, only the lead organization was able to attract/responsible for attracting other actors to be engaged in the project. As a consequence, only the lead organization attempted to develop the best practices for attracting external actors (e.g., case $\mathrm{H}$ was one of the first adopters of open innovation according to the secondary data). As stated by an informant of the case $\mathrm{H}$ : 
We (the leading organization) were able to involve the well-known "international non-governmental social development organization” .... We were able to do that thanks to our established best practices.

\subsection{Competence mapping capability}

The results for the competence-mapping capability suggest a twofold pattern similar to networking capability. First, all involved actors who considered this ability to be very important also faced challenges in putting the processes in practice and perceived the need for capability enhancement during the project (C, D, and E), particularly for mapping the sustainability competences of each actor. In these cases, all actors collaboratively dealt with this challenge through sharing their previous experiences, via regular explorative meetings to identify present competencies in each partner. During these projects, actors were typically co-developing an output together from the beginning of the project, when there was no clear idea of the final outcome and the required competence from each partner. On the other hand, in the second group of projects, the lead organization identified potential actors possessing the required knowledge/asset/competence (A, B, F, G, and H). Although these leading actors identified these capabilities as important, they did not experience many challenges during the projects, and they claimed that partners' competencies were easily recognizable, even in the sustainability context. In this regard, partners' competencies were easily recognizable because the particular requirements were clear and pre-defined from very beginning of the projects. For example, in case $\mathrm{B}$, the reason for integrating research centers was the need for waste-management technology, which was lacking among the internal competences of the lead organization. In these cases, the lead organizations were able to systematically evaluate diverse types of required 
assets, and accordingly, suitable actors could be engaged by documenting stakeholder competency assessments (Sharma and Vredenburg, 1998).

\subsection{Relational capability}

The results of cross-case analysis on relational capability show that five cases (C, D, E, F, and H) perceived the importance of building trust-based relationships with continuous goal identification and discussion exercises as a success factor but also a challenge. In these cases, the entire team that collaborated during all stages of the project attempted to establish continuous communication with frequent and intense decision-making processes (Ayuso et al., 2006). As the assistant manager of the innovation department in case F mentioned:

The main issue was to understand the cultural differences of the partner, as we were very different. So, we spent at least 10 or 11 months in the consortium agreement to discuss collaboratively.... We managed to have a very good relationship although we were very different.

Instead, in other cases, this capability seemed to be important but less of a challenge to develop for the lead organization, which was mainly responsible for managing the relationships, as the relationships were usually managed formally and/or by contract.

However, in all cases in which an actor is far from the lead organization's current business, which often happens in the sustainability context, e.g., NGOs, the challenges increase. In this regard, corporate affairs from case A mentioned:

It is difficult to integrate all types of actors. We are trying to improve, but it is not easy for us. Especially in sustainability projects, companies are learning how to 
communicate. This does not mean that we should not do it, but you have to find ways to communicate.

We argue that integrating actors who are far from the lead organization's business is challenging mainly for relational capability during SOI projects. The informants perceived that sustainability can facilitate relational capability building by establishing a shared sustainabilityrelated vision. As the technical development director in case B stated:

Projects related to sustainability are experienced in a more shared vision approach among diverse types of actors.

\subsection{Desorptive capacity}

Desorptive capacity includes the ability both to select and engage internal actors and to align and empower them according to external acquisitions. The results suggest that the two abilities were perceived as extremely important in all projects. The local marketing director from case B reported:

It is a critical success factor of the project to collaborate and align internally. If the company does not operate as a system, no project can be feasible.

The communication manager from case E mentioned:

You have to have a good relationship with the (external partners), e.g., users, but you have to have a good team working internally on top. It's not just one factor; it's the combination of them that is a success factor. Respondents claimed that a multidisciplinary perspective is required from various internal actors to incorporate sustainability issues during a project. Thus, engaging internal actors is fundamental because many functions of each partner should be engaged based on the same 
perception and conceptualization of the project. The energy and sustainability manager of a home appliance manufacturer from case $\mathrm{C}$ mentioned:

The difficulty of the SOI project is the need for multidisciplinary perspectives from different not only external but also internal actors in order to provide everything so that the final product functions properly.

However, aligning and empowering internal actors with stakeholders are perceived as much more challenging (cases C, D, E, and F) when the organizational differences between actors are substantial. In this case, employees of all involved organizations in all project phases are required to be trained particularly and continuously in terms of the specific project. In addition, various internal actors intensively participate during network meetings. Various mechanisms are used in all projects to be able to manage knowledge (e.g., designing a specific channel such as an online platform to distribute information and outcomes systematically). As the director of the research institution (lead organization) from case D stated:

There are shared documents... between individuals of organizations. Having done such a complex project, managing the knowledge through shared channels has led to growth for everyone, and we all learned something both as organizations and individuals.

In addition, as the assistant manager of the innovation department from case $\mathrm{F}$ mentioned:

Some engineers from the other partner have been here for the whole 4 years. Then, every 2 months, the project coordination committee integrates all the stakeholders to share the updated insights. This is necessary for the project process and internal-external integration and to find solutions. 
Finally, projects apply boundary teams. Boundary teams bridge disparate mindsets and languages by translating contrasting coding schemes and channel information between employees (Tushman, 1977). These mechanisms are used in addition to conventional ones to enhance the ability to integrate internal divisions (e.g., cross-functional teams, training, and social activities) (Maltz and Kohli, 2000). To conclude, all proposed capabilities are perceived as important for SOI development in all the cases. However, the emphasis on desorptive capability for the particular context of sustainability is noticeably higher compared to networking, competence mapping and relational capability.

To conclude, the summary of the analysis on each capability is provided in the following table. To do so and to be able to provide concrete findings for each capability, we show the result of each capability analysis in three measures:

1. The perceived importance of each capability for the actor(s) in each case (the final scale (1 to 5 ) is given for each capability in each case based on the coding scheme presented in Section 3.2)

2. The actor possessing the capability. In this regard, we examine whether solely the lead organization possesses the capability or whether in addition to the lead organization, key partners possess - and otherwise develop and utilize the capability.

3. The reconciliation requirement of each capability by the actor(s) in each case. In this regard, we examine whether the actor(s) in possession of the capability mainly relies on the already established open conventional innovations of their business or whether the capabilities require reconciliation during the SOI project. 
Table 5. Analysis of each capability

\begin{tabular}{|c|c|c|c|c|c|c|c|c|}
\hline Capability & A & $\mathbf{B}$ & $\mathrm{C}$ & D & $\mathbf{E}$ & $\mathbf{F}$ & $\mathbf{G}$ & $\mathbf{H}$ \\
\hline \multicolumn{9}{|l|}{ Networking } \\
\hline Perceived importance & 3 & 2 & 5 & 4 & 2 & 5 & 3 & 4 \\
\hline $\begin{array}{l}\text { Who possessed the } \\
\text { capability? }\end{array}$ & LEAD ORG. & $\begin{array}{l}\text { LEAD } \\
\text { ORG. }\end{array}$ & $\begin{array}{l}\text { Key } \\
\text { partners }\end{array}$ & $\begin{array}{l}\text { KEY } \\
\text { partners }\end{array}$ & $\begin{array}{l}\text { KEY } \\
\text { partners }\end{array}$ & $\begin{array}{l}\text { KEY } \\
\text { partners }\end{array}$ & $\begin{array}{l}\text { LEAD } \\
\text { ORG. }\end{array}$ & $\begin{array}{l}\text { KEY } \\
\text { partners }\end{array}$ \\
\hline $\begin{array}{l}\text { Whether the actor(s) in } \\
\text { possession of the } \\
\text { capability mainly relied } \\
\text { on the already established } \\
\text { open conventional } \\
\text { innovations of their } \\
\text { business or whether the } \\
\text { capabilities required } \\
\text { reconciliation during the }\end{array}$ & 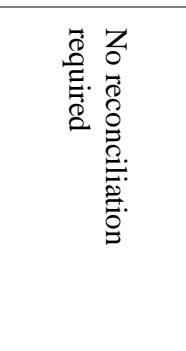 & 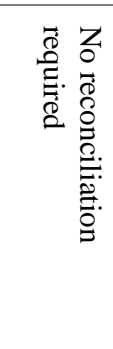 & 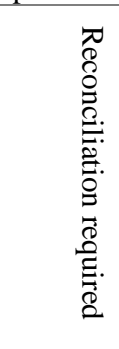 & 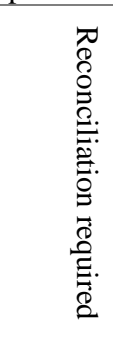 & 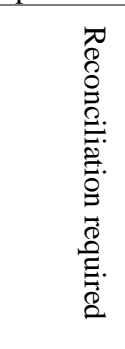 & 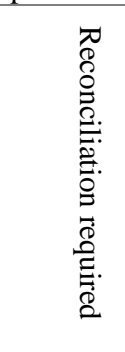 & 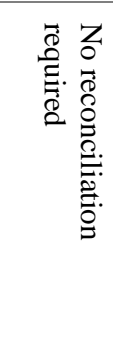 & 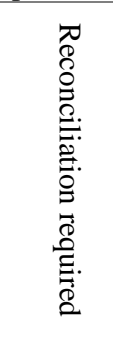 \\
\hline
\end{tabular}

\begin{tabular}{|c|c|c|c|c|c|c|c|c|}
\hline \multicolumn{9}{|l|}{ Competence mapping } \\
\hline Perceived importance & 2 & 3 & 5 & 5 & 4 & 5 & 3 & 4 \\
\hline $\begin{array}{l}\text { Who possessed the } \\
\text { capability? }\end{array}$ & LEAD ORG. & $\begin{array}{l}\text { LEAD } \\
\text { ORG. }\end{array}$ & $\begin{array}{l}\text { KEY } \\
\text { partners }\end{array}$ & $\begin{array}{l}\text { KEY } \\
\text { partners }\end{array}$ & $\begin{array}{l}\text { LEAD } \\
\text { ORG. }\end{array}$ & $\begin{array}{l}\text { KEY } \\
\text { partners }\end{array}$ & $\begin{array}{l}\text { LEAD } \\
\text { ORG. }\end{array}$ & $\begin{array}{l}\text { LEAD } \\
\text { ORG. }\end{array}$ \\
\hline $\begin{array}{l}\text { Whether the actor(s) in } \\
\text { possession of the } \\
\text { capability mainly relied } \\
\text { on the already established } \\
\text { open conventional } \\
\text { innovations of their } \\
\text { business or whether the } \\
\text { capabilities required } \\
\text { reconciliation during the }\end{array}$ & 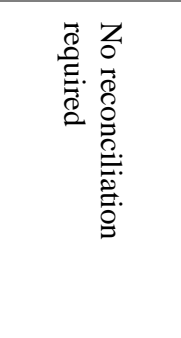 & 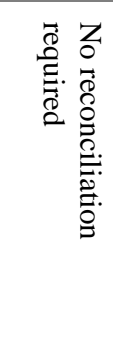 & 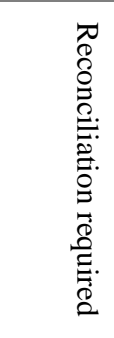 & 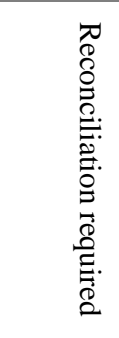 & 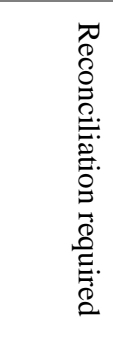 & 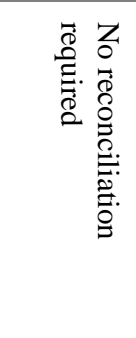 & 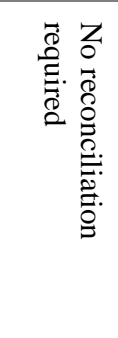 & 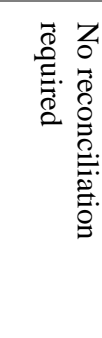 \\
\hline
\end{tabular}

SOI project.

\begin{tabular}{|c|c|c|c|c|c|c|c|c|}
\hline \multicolumn{9}{|l|}{ Relational Capability } \\
\hline Perceived importance & 3 & 2 & 5 & 5 & 4 & 4 & 3 & 4 \\
\hline $\begin{array}{l}\text { Who possessed the } \\
\text { capability? }\end{array}$ & LEAD ORG. & $\begin{array}{l}\text { LEAD } \\
\text { ORG. }\end{array}$ & $\begin{array}{l}\text { KEY } \\
\text { partners }\end{array}$ & $\begin{array}{l}\text { KEY } \\
\text { partners }\end{array}$ & $\begin{array}{l}\text { LEAD } \\
\text { ORG. }\end{array}$ & $\begin{array}{l}\text { KEY } \\
\text { partners }\end{array}$ & $\begin{array}{l}\text { LEAD } \\
\text { ORG. }\end{array}$ & $\begin{array}{l}\text { KEY } \\
\text { partners }\end{array}$ \\
\hline $\begin{array}{l}\text { Whether the actor(s) in } \\
\text { possession of the } \\
\text { capability mainly relied } \\
\text { on the already established } \\
\text { open conventional } \\
\text { innovations of their } \\
\text { business or whether the } \\
\text { capabilities required } \\
\text { reconciliation during the } \\
\text { SOI project. }\end{array}$ & 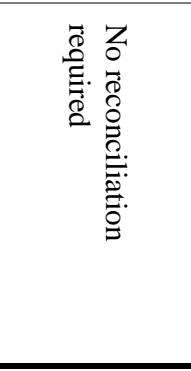 & 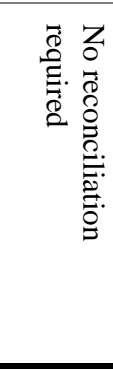 & 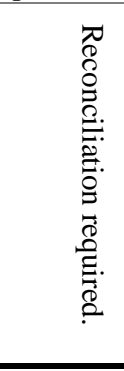 & 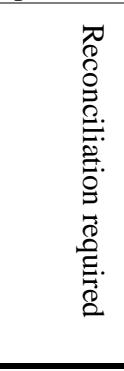 & 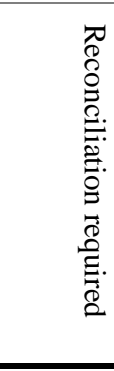 & 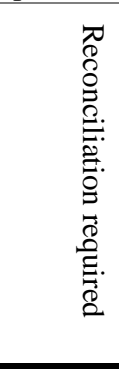 & 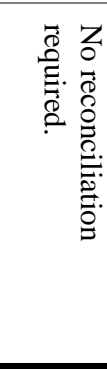 & 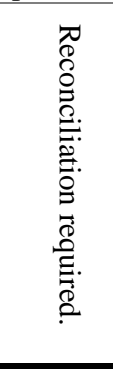 \\
\hline \multicolumn{9}{|l|}{ Desorptive Capacity } \\
\hline Perceived importance & 4 & 5 & 5 & 5 & 5 & 4 & 4 & 5 \\
\hline $\begin{array}{l}\text { Who possessed the } \\
\text { capability? }\end{array}$ & LEAD ORG. & $\begin{array}{l}\text { LEAD } \\
\text { ORG. }\end{array}$ & $\begin{array}{l}\text { KEY } \\
\text { partners }\end{array}$ & $\begin{array}{l}\text { KEY } \\
\text { partners }\end{array}$ & $\begin{array}{l}\text { LEAD } \\
\text { ORG. }\end{array}$ & $\begin{array}{l}\text { KEY } \\
\text { partners }\end{array}$ & $\begin{array}{l}\text { LEAD } \\
\text { ORG. }\end{array}$ & $\begin{array}{l}\text { KEY } \\
\text { partners }\end{array}$ \\
\hline $\begin{array}{l}\text { Whether the actor(s) in } \\
\text { possession of the } \\
\text { capability mainly relied } \\
\text { on the already established } \\
\text { open conventional } \\
\text { innovations of their } \\
\text { business or whether the } \\
\text { capabilities required } \\
\text { reconciliation during the } \\
\text { SOI project. }\end{array}$ & 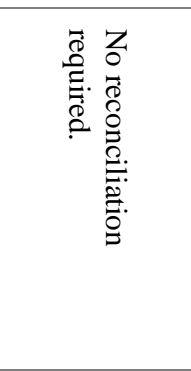 & 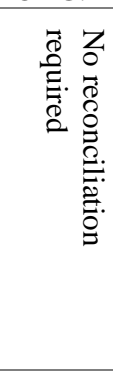 & . & . & 苗 & & 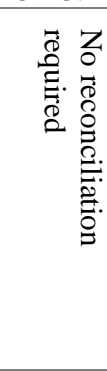 & 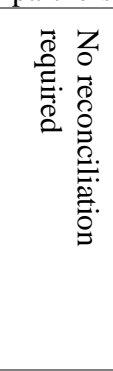 \\
\hline
\end{tabular}




\subsection{Overall analysis of the findings}

Building upon the analysis on each capability, we were able to carry out an overall analysis to draw out findings in order to answer the research question, namely, which open innovation capabilities should be reconciled by firms for particular innovations aimed at sustainability depending on the radicalism and the product/service combination of the output? To do so, we classified our cases into unidimensional and systemic innovations based on the theoretical background. Accordingly, cases A, B, G, and H are unidimensional innovations, and cases C, D, $\mathrm{E}$, and $\mathrm{F}$ are systemic innovations.

The results reveal that external integration capability building differs depending on the outcome characteristics. The synthesized insights suggest that project members of systemic SOIs typically face greater challenges in exploring and exploiting sustainability issues in innovations compared to unidimensional project members, which leads key actors to possess exploration/exploitation capabilities for the particular context of sustainability or to develop a collaborative capability together. Finally, desorptive capacity seems to require reconciliation, not only for systemic SOIs, but also for unidimensional SOIs, as aligning and empowering internal functions on sustainability issues is challenging. Thus, we can conclude that all key actors of systemic SOIs should possess all open innovation capabilities; thus, they must develop them, if they are not already possessed. In contrast, in unidimensional SOIs only lead organizations (should) possess the capabilities and potentially enhance their established desorptive capacity according to the particular context of sustainability.

To conclude, we argue that unidimensional SOIs can be developed by relying on established open innovation capabilities while mainly reconciling desorptive capacity - by aligning and empowering internal functions to the particular sustainability context. However, in 
systemic SOIs, reconciliation is required for all open innovation capabilities. Regarding exploration and exploitation capabilities, all key actors should develop, if they are not already possessed, the capabilities or build a collaborative capability. Based on the cases, we can also suggest the following mechanisms to collaboratively build capabilities together: continuously and extensively communicating, jointly engaging in various networking opportunities; jointly exploring various potential actors; continuously conducting goal identification exercises, and not only relying on typical information-sharing routines within the boundaries of each actor but applying boundary-breaking routines. Finally, the results show that when actors have organizational differences - as is typical in the sustainability context - regardless of the outcome characteristics, exploitation and retention capabilities are much more challenging to develop and require reconciliation.

To conclude, the cross-case analysis reveals that the degree of importance, requirement of reconciliation and liability of possessing capabilities differ depending on the innovation type for each capability. In this regard, the findings of the study are presented in the following figure (Fig. 1). 
Figure 1 - The findings from the cross-case analysis regarding the required reconciliation of

conventional open innovations for developing open innovations particularly aimed at sustainable development (sustainability-oriented innovation)

\section{Conventional Open \\ Innovation \\ Capabilities}

\begin{tabular}{l} 
Networking \\
ability to attract \\
relevant external \\
actors for innovations \\
\hline Competence \\
mapping \\
ability to identify the \\
map of competences \\
of existing/potential \\
partners
\end{tabular}

Open innovation capabilities for sustainability

\begin{tabular}{l|l}
\hline \hline $\begin{array}{l}\text { Develop/co-create a sustainable system } \\
\text { of product(s) and service(s) as well as } \\
\text { supporting infrastructure that disrupt the } \\
\text { existing system (systemic SOIs) }\end{array}$ & $\begin{array}{l}\text { Develop an innovative sustainable } \\
\text { product or service that does not } \\
\text { disruptively change the existing } \\
\text { systems and users'behaviors } \\
\text { (unidimensional SOIs) }\end{array}$ \\
\hline
\end{tabular}

\begin{tabular}{l}
\hline Diversification of \\
networking capability to \\
the external actors, esp. \\
the sustainability \\
experts/individuals/NGOs \\
who may be far from the \\
leading business \\
\hline Collaborative \\
competence mapping \\
between key partners is \\
required since sustainable
\end{tabular}
experts' competence mapping is often outside the conventional open innovation capabilities of the businesses.

Structured relationship management mechanisms required to cope with the intense relationships of co-creation (similar to conventional innovations), in addition a structured methodology for esp. sustainable NGOs and individuals who may have conflicts of interest with the project consortium

\begin{tabular}{|c|c|c|}
\hline $\begin{array}{l}\text { All key } \\
\text { actors } \\
\text { involved in } \\
\text { the project } \\
\text { should } \\
\text { develop -if } \\
\text { not already } \\
\text { possessed - } \\
\text { the } \\
\text { capabilities }\end{array}$ & $\begin{array}{l}\text { Can rely on } \\
\text { conventional open } \\
\text { innovation } \\
\text { capabilities of the } \\
\text { lead open } \\
\text { organization } \\
\text { As with } \\
\text { conventional open } \\
\text { innovations, in } \\
\text { case of involved } \\
\text { partners, which are } \\
\text { far from the lead } \\
\text { organization's } \\
\text { business, } \\
\text { structured } \\
\text { relationship } \\
\text { management } \\
\text { mechanisms may } \\
\text { be required. } \\
\text { However, the } \\
\text { sustainability } \\
\text { context typically } \\
\text { requires that more } \\
\text { projects involve } \\
\text { partners that are far } \\
\text { from the lead } \\
\text { organization's } \\
\text { business }\end{array}$ & $\begin{array}{l}\text { The lead } \\
\text { organization } \\
\text { should possess } \\
\text { the } \\
\text { conventional } \\
\text { open } \\
\text { innovations }\end{array}$ \\
\hline
\end{tabular}

Reconciliation is especially needed to reinforce and structure desorptive capacity. Some practices for such reconciliation can be suggested based on this study's cases. Primarily, the enhancement of internal coordination is required to focus on the particular context (sustainability) of innovation. This study's cases suggest some practices to enhance cross-functional coordination, including assigning crossfunctional teams, boundary people, social activities, and specific training for coordination.

\section{Discussion}

This study examines open innovation capabilities when innovations are aimed particularly at sustainable development. Starting from a conceptual capability framework for open conventional 
innovations, eight SOI projects were taken as an empirical context for a qualitative, multiplecase study. The conceptual framework, in particular, identifies four constitutive capabilities namely, networking, competency mapping, relational and desorptive capabilities. The purpose of this study is to confront extant theory on sustainable development by relying on the sustainability-oriented innovation research stream and to address such theory on open innovation by investigating the specific context of the sustainability of innovations as the empirical setting. The results of the study advance insights for theory and practice in two key respects.

First, the results suggest that distinctions in open sustainable innovation capabilities must be made depending on the innovation type in terms of who should possess the capabilities. In particular, our cases suggest the relevance of differentiation between two types of innovations: innovations aimed at developing an innovative product or service, which incrementally modify the existing systems, and innovations aimed at developing a product-service system, which disruptively change user behavior. In the particular context of sustainability, our results open a research window by showing that in the case of developing an innovative sustainable product or service, mainly the lead organization should possess/develop the capabilities; however, in PSS development, key actors - not merely the lead organization - should build (collaboratively) open innovation capabilities, if they are not already possessed. In particular, the specific sustainability context engenders peculiarities in PSS development, such as the diversification of networking capability among all key partners, collaborative competence mapping and structured relationship management mechanisms. Regarding the competence mapping and relational capabilities, there are a few studies on the structured mechanisms for customer competence mapping by firms (e.g., Bueren et al., 2005) or bidirectional business/NGOs interaction (Valor and Diego, 2009; van Huijstee and Glasbergen, 2010). Further, our results show the relevance of innovative PSS 
development in future investigations in the specific sustainability context on collaborative competence mapping tools/instruments for networks and specifically for actors far from the business perspective (which is often is case when sustainability goals are in the place for innovation).

Second, the capability of firms to align internals to external integration is seen to be influenced by the sustainability context in all cases (not only in PSS cases, which disruptively modify the existing systems, but also when firms develop an innovative product or service for sustainability with incremental implications for user behavior). This study adds insights to contemporary innovation research in the specific sustainability context focused on internal alignment/empowerment for external integration - integrative capability (e.g., Ayuso et al., 2011; Hillebrand and Biemans, 2004; Verona, 1999). In this regard, our cases show that within the sustainability context, innovation requires advanced degrees of internal cooperation for external coordination, even more so than similar conventional innovations because sustainable expert stakeholders are often far from business perspective of the project (Hillebrand and Biemans (2004) call for advanced internal cooperation in conventional innovations). The cases in this study developed some practices for aligning and empowering the internal actors to external integration for the specific sustainability context. The practices not only target basic enhancement in internal cooperation (e.g., cross-functional teams, training, social activities (Maltz and Kohli, 2000)) but also include advanced practices to reduce the gap caused by differences in mind-sets, languages, time frames, and norms among employees (Dougherty, 1992) (e.g., employment of people who transfer information among organizational groups referred to as boundary persons (Tushman, 1977)). While this study affirms the relevance of prior SOI investigations on the link between desorptive capacity and relational capability (Ayuso 
et al., 2011; Veldhuizen et al., 2012), we show the need for further qualitative studies (e.g., longitudinal) on how businesses/networks develop desorptive capacity over the transition toward engaging strategically in SOI development (Hillebrand and Biemans, 2004).

The results of the study are aligned with prior literature in several respects. First, as anticipated, the results are aligned with studies arguing for the appropriateness of innovation frameworks/theories for SOI investigations (Pujari et al., 2003). Second, as foreseen, the SOI cases of this study show the peculiarities of innovations in the sustainability context compared to conventional forms of innovation - in terms of the required capabilities for the integration of external actors (Pujari, 2006; van Kleef and Roome, 2007). Third, this study confirms that actors in the sustainability context are typically highly diverse from an organizational perspective with respect to supporting creativity in this context (e.g., including both profit versus non-profit organizations and individuals/sustainability activists) (Clarke and Roome, 1995; Dangelico et al., 2013; van Kleef and Roome, 2007). However, we argue that there have been few investigations on the management of disparate types of actors in innovation projects for sustainability (e.g., Ayuso et al., 2011), especially with respect to social innovations and supporting instruments. This study argues that investigations on open SOI projects should consider the dependence of capabilities on the output characteristics (Carrillo-Hermosilla et al., 2010). This is aligned with previous studies suggesting the necessity of investigations considering both approaches (incremental and systemic) in sustainable development (Carrillo-Hermosilla et al., 2010). However, we propose that the dual approaches seem to be disjointed and that integrative perspectives may help practitioners to be better able to differentiate business initiatives. 


\section{Conclusion}

The integration of a broad set of actors in innovations is important because stakeholders enhance and exploit innovative potential by providing unexpected insights and perspectives that lie outside a firm's scope. However, it can also be a very complex process. This study examines external integration capabilities in innovations within the particular context of sustainability. Insights from a capability view and open innovation view serve as the theoretical perspective to guide this empirical research. Starting from the open innovation literature and considering exploration, exploitation and retention capabilities as the theoretical foundation, we identified four capabilities for external integration, namely, networking, competence mapping, relational and desorptive capabilities. Eight sustainability-oriented innovation (SOI) projects in firms were scrutinized. The results from this study provide contributions regarding the role of capabilities in enhancing a firm's sustainable development through innovation. The empirical setting of the study is aligned with the capability view of sustainability because innovation frameworks/theories are appropriate for SOI investigations.

The results also suggest that a distinction is required among types of projects and that not all types of SOIs stress capabilities equally. In this study, this distinction was made according to the outcome characteristics - product/service combination and radicalism of the output.

Innovations aimed at developing a specific product or service in the existing system for sustainable development can be developed by relying on established open innovation capabilities while mainly reconciling desorptive capacity - by aligning and empowering internal functions to the particular sustainability context. However, in SOIs involving disruptive changes to existing systems by developing a mix of product-service system, reconciliation for exploration and 
exploitation capabilities is also required. In this regard, all key actors should develop, if they do not already possess, the capabilities or build a collaborative capability.

From a managerial perspective, one question that firms engaging in complex and uncertain sustainable initiatives must address is how to reconcile open innovation capabilities for this particular context. This study helps managers of innovative firm planning to engage in sustainable development by offering an initial guide for the reconciliation of open innovation capabilities.

This study had some limitations, some of which offer further research avenues. First, the findings of this research rely on interviews in only eight cases. Future research should include more cases covering other types of actors that extend the scope of this topic. Further research can also focus on other types of disparities within outcome characteristics to further elucidate influencing factors. Last but not least, further investigations should investigate the ways in which collaborative open innovation capabilities can be built among project members. It should be noted that the suggested assessment of open innovation capabilities is subjective, not only because the information is incomplete, but also because we offer interpretations and use a graded scale of importance. More research can expand the diversification of views and interpretations to build a unified conclusion.

\section{Acknowledgements}

For their invaluable feedback, we owe special thanks to the anonymous reviewers of the manuscript. Special acknowledgment goes to John Garger and American Journal Experts for their professional English proof reading assistance. This paper was produced as part of the EMJD Programme European Doctorate in Industrial Management (EDIM), funded by the 
European Commission, Erasmus Mundus Action 1. This research was also partially part of the European research project "Sustainable Lifestyles 2.0: End User Integration, Innovation and Entrepreneurship (EU-InnovatE - the European Union's Seventh Framework Programme for research, technological development, and demonstration under grant agreement number 61319).

\section{Conflict of interest}

'Conflicts of interest: none'

\section{Funding sources}

This work was supported by the European Commission, Erasmus Mundus Action 1.

\section{Role of the funding source}

The funding source provided financial support for the conduct of the research and not been involved in preparation of the article.

\section{References}

Adams, R., Jeanrenaud, S., Bessant, J., Denyer, D., Overy, P., 2016. Sustainability-oriented innovation: a systematic review. Int. J. Manag. Rev. 18, 180-205.

Adams, R.J., Bessant, J., Jeanrenaud, S., Overy, P., Denyer, D., 2012. Innovating for sustainability: a systematic review of the body of knowledge, Network for Business Sustainability.

Alvesson, M., Sköldberg, K., 2009. Reflexive Methodology: New Vistas for Qualitative Research. Sage Publications Ltd, London.

Amit, R., Schoemaker, P.J.H., 1993. Strategic assets and organizational rent. Strateg. Manag. J. 14, 33-46.

Andrews, K.R., 1971. The Concept of Corporate Strategy. Dow Jones-Irwin, Homewood, IL. 
Argyris, C., Schön, D.A., 1997. Organizational learning: a theory of action perspective. Reis (77/78), 345-348.

Ayuso, S., Rodríguez, M.A., García-Castro, R., Ariño, M.A., 2011. Does stakeholder engagement promote sustainable innovation orientation? Ind. Manag. Data Syst. 111, 1399-1417.

Ayuso, S., Rodríguez, M.A., Ricart, J.E., 2006. Using stakeholder dialogue as a source for new ideas: a dynamic capability underlying sustainable innovation. Corp. Gov.: Int. J. Bus. Soc. 6, 475-490.

Baines, T.S., Lightfoot, H.W., Evans, S., Neely, A., Greenough, R., Peppard, J., Roy, R., Shehab, E., Braganza, A., Tiwari, A., 2007. State-of-the-art in product-service systems. Proc. Inst. Mech. Eng. B J. Eng. Manuf. 221, 1543-1552.

Belz, F.M., 2013. Shaping the future: sustainable innovation and entrepreneurship. Soc. Bus. 3, $311-324$.

Bos-Brouwers, H.E.J., 2010. Corporate sustainability and innovation in SMEs: evidence of themes and activities in practice. Bus. Strategy Environ. 19, 417-435.

Brown, B.J., Hanson, M.E., Liverman, D.M., Merideth, R.W., 1987. Global sustainability: toward definition. Environ. Manag. 11, 713-719.

Bueren, A., Schierholz, R., Kolbe, L.M., Brenner, W., 2005. Improving performance of customer-processes with knowledge management. Bus. Process Manag. J. 11, 573-588.

Campbell, D.T., 1960. Blind variation and selective retentions in creative thought as in other knowledge processes. Psychol. Rev. 67, 380.

Capaldo, A., 2007. Network structure and innovation: the leveraging of a dual network as a distinctive relational capability. Strateg. Manag. J. 28, 585-608. 
Carrillo-Hermosilla, J., del Río, P., Könnölä, T., 2010. Diversity of eco-innovations: reflections from selected case studies. J. Clean. Prod. 18, 1073-1083.

Carter, C.R., Rogers, D.S., 2008. A framework of sustainable supply chain management: moving toward new theory. Int. J. Phys. Distrib. Logist. Manag. 38, 360-387.

Charmez, K., 1983. The grounded theory method: an explication and interpretation, in: Emerson, R.M. (Ed.), Contemporary Field Research: A Collection of Readings. Little, Brown and Company, Boston, pp. 109-126.

Chesbrough, H., Bogers, M., 2014. Explicating open innovation: clarifying an emerging paradigm for understanding innovation, in: Chesbrough, H.W., Vanhaverbeke, W., West, J. (Eds.), New Frontiers in Open Innovation. Oxford University Press, Oxford, UK, pp. 3-28.

Christensen, C.M., 1997. The Innovator's Dilemma: When New Technologies Cause Great Firms to Fail. Harvard Business School Press, Boston.

Clarke, S.F., Roome, N.J., 1995. Managing for environmentally sensitive technology: networks for collaboration and learning. Technol. Anal. Strateg. Manag. 7, 191-216.

Cohen, W.M., Levinthal, D.A., 1990. Absorptive capacity: a new perspective on learning and innovation. Adm. Sci. Q. 35, 128-152.

Cornell, B., Shapiro, A.C., 1987. Corporate stakeholders and corporate finance. Financ. Manag. 16, 5-14.

Dangelico, R.M., Pontrandolfo, P., Pujari, D., 2013. Developing sustainable new products in the textile and upholstered furniture industries: role of external integrative capabilities. J. Prod. Innov. Manag. 30, 642-658. 
Dangelico, R.M., Pujari, D., 2010. Mainstreaming green product innovation: why and how companies integrate environmental sustainability. J. Bus. Ethics 95, 471-486.

de Marchi, V., 2012. Environmental innovation and R\&D cooperation: empirical evidence from Spanish manufacturing firms. Res. Policy 41, 614-623.

de Medeiros, J.F., Ribeiro, J.L.D., Cortimiglia, M.N., 2014. Success factors for environmentally sustainable product innovation: a systematic literature review. J. Clean. Prod. 65, 76-86. Dougherty, D., 1992. Interpretive barriers to successful product innovation in large firms. Organ. Sci. 3, 179-202.

Driessen, P.H., Hillebrand, B., 2013. Integrating multiple stakeholder issues in new product development: an exploration. J. Prod. Innov. Manag. 30, 364-379.

Eisenhardt, K.M., Martin, J.A., 2000. Dynamic capabilities: what are they? Strateg. Manag. J. 21, 1105-1121.

Elkington, J., 1997. Cannibals with Forks: The Triple Bottom Line of 21st Century Business. New Society Publishers, Gabriola Island, Canada.

Foster, C., Green, K., 2000. Greening the innovation process. Bus. Strategy Environ. 9, 287-303.

Foxon, T., Andersen, M.M., 2009. The greening of innovation systems for eco-innovationtowards an evolutionary climate mitigation policy, in: DRUID Summer Conference on Innovation, Strategy and Knowledge. Copenhagen Business School, Copenhagen, Denmark, pp. 1-35.

Freeman, C., Perez, C., 1988. Structural crises of adjustment, business cycles and investment behaviour, in: Dosi, G., Freeman, C., Nelson, R., Silverberg, G., Soete, L. (Eds.), Technical Change and Economic Theory. Pinter Publishers, London, pp. 38-66. 
Freeman, R.E., Evan, W.M., 1990. Corporate governance: a stakeholder interpretation. J. Behav. Econ. 19, 337-359.

Fussler, C., James, P., 1996. A Breakthrough Discipline for Innovation and Sustainability. Pitman Publishing, London.

Gassmann, O., Enkel, E., Chesbrough, H., 2010. The future of open innovation. R\&D Manag. 40, 213-221.

Gmelin, H., Seuring, S., 2014. Determinants of a sustainable new product development. J. Clean. Prod. 69, 1-9.

Gould, R.W., 2012. Open innovation and stakeholder engagement. J. Technol. Manag. Innov. 7, $1-11$.

Grafé-Buckens, A., Hinton, A.F., 1998. Engaging the stakeholders: corporate views and current trends. Bus. Strategy Environ. 7, 124-133.

Griffin, A., Hauser, J.R., 1996. Integrating R\&D and marketing: a review and analysis of the literature. J. Prod. Innov. Manag. 13, 191-215.

Hall, J., 2002. Sustainable development innovation; a research agenda for the next 10 yearsEditorial for the 10 th Anniversary of the Journal of Cleaner Production. J. Clean. Prod. 10, 195-196.

Hall, J., Vredenburg, H., 2003. The challenge of innovating for sustainable development. MIT Sloan Manag. Rev. 45, 61.

Hansen, E.G., Grosse-Dunker, F., Reichwald, R., 2009. Sustainability innovation cube-a framework to evaluate sustainability-oriented innovations. Int. J. Innov. Manag. 13, 683713.

Hart, S.L., 1995. A natural-resource-based view of the firm. Acad. Manag. Rev. 20, 986-1014. 
Hart, S.L., 1997. Beyond greening: strategies for a sustainable world. Harv. Bus. Rev. 75, 66-77. Hill, C.W.L., Jones, T.M., 1992. Stakeholder-agency theory. J. Manag. Stud. 29, 131-154.

Hillebrand, B., Biemans, W.G., 2003. The relationship between internal and external cooperation. J. Bus. Res. 56, 735-743.

Hillebrand, B., Biemans, W.G., 2004. Links between internal and external cooperation in product development: an exploratory study. J. Prod. Innov. Manag. 21, 110-122.

Hofer, C.W., Schendel, D., 1978. Strategy Formulation: Analytical Concepts. West Publishing Company, St. Paul, Minnesota.

Horn, C., Brem, A., 2013. Strategic directions on innovation management-a conceptual framework. Manag. Res. Rev. 36, 939-954.

Huizingh, E.K.R.E., 2011. Open innovation: state of the art and future perspectives. Technovation 31, 2-9.

Jelsma, J., 2003. Innovating for sustainability: involving users, politics and technology. Innov.: Eur. J. Soc. Sci. Res. 16, 103-116.

Kale, P., Singh, H., 2007. Building firm capabilities through learning: the role of the alliance learning process in alliance capability and firm-level alliance success. Strateg. Manag. J. 28, 981-1000.

Kazadi, K., Lievens, A., Mahr, D., 2016. Stakeholder co-creation during the innovation process: identifying capabilities for knowledge creation among multiple stakeholders. J. Bus. Res. 69, 525-540.

Kemp, R., Pearson, P., 2008. Measuring Eco-innovation. United Nations University, Maastricht. Keskin, D., Diehl, J.C., Molenaar, N., 2013. Innovation process of new ventures driven by sustainability. J. Clean. Prod. 45, 50-60. 
Ketata, I., Sofka, W., Grimpe, C., 2015. The role of internal capabilities and firms' environment for sustainable innovation: evidence for Germany. R\&D Manag. 45, 60-75.

Klewitz, J. and Hansen, E.G., 2014. Sustainability-oriented innovation of SMEs: a systematic review. Journal of Cleaner Production, 65, 57-75.

Koebel, C.T., 1999. Sustaining sustainability: innovation in housing and the built environment. J. Urban Technol. 6, 75-94.

Könnölä, T., Unruh, G.C., 2007. Really changing the course: the limitations of environmental management systems for innovation. Bus. Strategy Environ. 16, 525-537.

Lane, P.J., Koka, B.R., Pathak, S., 2006. The reification of absorptive capacity: a critical review and rejuvenation of the construct. Acad. Manag. Rev. 31, 833-863.

Laperche, B., Picard, F., 2013. Environmental constraints, product-service systems development and impacts on innovation management: learning from manufacturing firms in the French context. J. Clean. Prod. 53, 118-128.

Lichtenthaler, U., 2007. The drivers of technology licensing: an industry comparison. Calif. Manag. Rev. 49, 67-89.

Lichtenthaler, U., 2011. Open innovation: past research, current debates, and future directions. Acad. Manag. Perspect. 25, 75-93.

Lichtenthaler, U., Lichtenthaler, E., 2009. A capability-based framework for open innovation: complementing absorptive capacity. J. Manag. Stud. 46, 1315-1338.

Linton, J.D., Klassen, R., Jayaraman, V., 2007. Sustainable supply chains: an introduction. J. Oper. Manag. 25, 1075-1082.

Lockton, D., Harrison, D., Stanton, N., 2008. Making the user more efficient: design for sustainable behaviour. Int. J. Sustain. Eng. 1, 3-8. 
Lorenzoni, G., Lipparini, A., 1999. The leveraging of interfirm relationships as a distinctive organizational capability: a longitudinal study. Strateg. Manag. J. 20, 317-338.

Mahoney, J., 2000. Path dependence in historical sociology. Theory Soc. 29, 507-548.

Maltz, E., Kohli, A.K., 2000. Reducing marketing’s conflict with other functions: the differential effects of integrating mechanisms. J. Acad. Mark. Sci. 28, 479-492.

Manzini, E., Vezzoli, C., 2003. A strategic design approach to develop sustainable product service systems: examples taken from the ‘environmentally friendly innovation’ Italian prize. J. Clean. Prod. 11, 851-857.

Markides, C., 2006. Disruptive innovation: in need of better theory. J. Prod. Innov. Manag. 23, $19-25$.

Mitrega, M., Forkmann, S., Ramos, C., Henneberg, S.C., 2012. Networking capability in business relationships-concept and scale development. Ind. Mark. Manag. 41, 739-751.

Mont, O.K., 2002. Clarifying the concept of product-service system. J. Clean. Prod. 10, 237-245.

Morand, F., 2008. Developing eco-innovation: opportunities for education and policy integration. Ecoinnovation Network. http://www.eco-innovation.net/developing-ecoinnovation (accessed 24.09.14).

Neely, A., 2008. Exploring the financial consequences of the servitization of manufacturing. Oper. Manag. Res. 1, 103-118.

Nelson, R.R., Winter, S.G., 1982. The schumpeterian tradeoff revisited. Am. Econ. Rev. 72, $114-132$.

Nidumolu, R., Prahalad, C.K., Rangaswami, M.R., 2009. Why sustainability is now the key driver of innovation. Harv. Bus. Rev. 87, 56-64.

Nonaka, I., 2007. The knowledge creating company. Harv. Bus. Rev. 85, 162-171. 
OECD, 2009. Sustainable Manufacturing and Eco-innovation. Framewok, Practices and Measurement. Synthesis Report, OECD, Paris.

Patton, M.Q., 1990. Qualitative Evaluation and Research Methods. SAGE Publications, Thousand Oaks, CA, USA.

Perks, H., Moxey, S., 2011. Market-facing innovation networks: how lead firms partition tasks, share resources and develop capabilities. Ind. Mark. Manag. 40, 1224-1237.

Perl-Vorbach, E., Rauter, R., Baumgartner, R.J., 2014. Open innovation in the context of sustainable innovation: findings based on a literature review, in: 9th International Symposium on Sustainable Leadership. Salzburg, Austria, pp. 169.

Perry, S.J., 2015. Perry, S.J., Organized Innovation: A Framework for Effectively Managing Innovation. age, 26, 1.

Peteraf, M.A., 1993. The cornerstones of competitive advantage: a resource-based view. Strateg. Manag. J. 14, 179-191.

Prahalad, C.K., Hamel, G., 1990. The core competence of the corporation. Harv. Bus. Rev. 68, 79-91.

Pujari, D., Wright, G. and Peattie, K., 2003. Green and competitive: influences on environmental new product development performance. Journal of business Research, 56(8), 657-671.

Pujari, D., 2006. Eco-innovation and new product development: understanding the influences on market performance. Technovation 26, 76-85.

Rivette, K.G., Kline, D., 2000. A hidden weapon for high-tech battles. Upside. January, 165174.

Rogers, P.P., Jalal, K.F., Boyd, J.A., 2012. An Introduction to Sustainable Development. Earthscan, London. 
Sarkis, J., Cordeiro, J.J., Brust, D.V., 2010. Facilitating Sustainable Innovation through

Collaboration: A Multi-Stakeholder Perspective. Springer, Dordrecht, Netherlands.

Schumpeter, J.A., 1939. Business Cycles, vol. 1. McGraw-Hill, New York.

Seebode, D., Jeanrenaud, S., Bessant, J., 2012. Managing innovation for sustainability. R\&D Manag. 42, 195-206.

Sharma, S., Vredenburg, H., 1998. Proactive corporate environmental strategy and the development of competitively valuable organizational capabilities. Strateg. Manag. J. 19, 729-753.

Steiner, G., 2008. Supporting sustainable innovation through stakeholder management: a systems view. Int. J. Innov. Learn. 5, 595-616.

Strong, K.C., Ringer, R.C., Taylor, S.A., 2001. The rules of stakeholder satisfaction (timeliness, honesty, empathy). J. Bus. Ethics 32, 219-230.

Tukker, A., Butter, M., 2007. Governance of sustainable transitions: about the 4(0) ways to change the world. J. Clean. Prod. 15, 94-103.

Tukker, A., Tischner, U., 2006. Product-services as a research field: past, present and future. Reflections from a decade of research. J. Clean. Prod. 14, 1552-1556.

Tushman, M.L., 1977. Special boundary roles in the innovation process. Adm. Sci. Q. 22, 587605.

Ulrich, D., Lake, D., 1991. Organizational capability: creating competitive advantage. Executive 5, 77-92.

Valor, C., Diego, A.M.D., 2009. Relationship of business and NGOs: an empirical analysis of strategies and mediators of their private relationship. Bus. Ethics: Eur. Rev. 18, 110-126. 
van de Vrande, V., de Jong, J.P.J., Vanhaverbeke, W., de Rochemont, M., 2009. Open innovation in SMEs: trends, motives and management challenges. Technovation 29, $423-437$.

van Halen, C., Vezzoli, C., Wimmer, R., 2005. Methodology for Product Service System Innovation: How to Develop Clean, Clever and Competitive Strategies in Companies. Koninklijke Van Gorcum, Assen.

van Huijstee, M.V., Glasbergen, P., 2010. NGOs moving business: an analysis of contrasting strategies. Bus. Soc. 49, 591-618.

van Kleef, J.A.G., Roome, N.J., 2007. Developing capabilities and competence for sustainable business management as innovation: a research agenda. J. Clean. Prod. 15, 38-51.

van Lancker, J., Mondelaers, K., Wauters, E., van Huylenbroeck, G., 2016. The organizational innovation system: a systemic framework for radical innovation at the organizational level. Technovation 52, 40-50.

Vandermerwe, S., Rada, J., 1988. Servitization of business: adding value by adding services. Eur. Manag. J. 6, 314-324.

Veldhuizen, M.T., Blok, V. and Dentoni, D., 2012. Multi-stakeholder interaction as a source for sustainable development: organisational drivers determining firms’'stakeholder dialogue’and ‘knowledge integration’capabilities. In: Wageningen University and Research centre.

Verhoeven, K.B.T., Maritz, A., 2012. Collaboration for innovation: network processes and capabilities, In ISPIM Conference Proceedings (p. 1). The International Society for Professional Innovation Management (ISPIM). Manchester, England. 
Verona, G., 1999. A resource-based view of product development. Acad. Manag. Rev. 24, 132142.

VINNOVA, 2001. Drivers of Environmental Innovation. VINNOVA Innovation in Focus VF 2001:1. VINNOVA - Swedish Governmental Agency for Innovation Systems, Stockholm, pp. 66.

Wagner, M., Llerena, P., 2008. Drivers for Sustainability-Related Innovation: A Qualitative Analysis of Renewable Resources, Industrial Products and Travel Services. Working Papers of BETA 2008-22, Bureau d'Economie Théorique et Appliquée, UDS, Strasbourg.

WCED (World Commission for Environment and Development), 1987. Our Common Future. Report of the World Commission on Environment and Development, Oxford University Press, Oxford.

West, J., Bogers, M., 2014. Leveraging external sources of innovation: a review of research on open innovation. J. Prod. Innov. Manag. 31, 814-831.

Williams, A., 2007. Product service systems in the automobile industry: contribution to system innovation? J. Clean. Prod. 15, 1093-1103.

Ye, J., Kankanhalli, A., 2013. Exploring innovation through open networks: a review and initial research questions. IIMB Manag. Rev. 25, 69-82.

Yin, R.K., 2013. Case Study Research: Design and Methods, vol. 5. SAGE Publications, London, United Kingdom.

Zollo, M., Winter, S.G., 2002. Deliberate learning and the evolution of dynamic capabilities. Organ. Sci. 13, 339-351. 